\title{
Parts of the Whole: Teachers and the Work They Do
}

\section{Dorothy Wallace}

Dartmouth College, dorothy.wallace@dartmouth.edu

Follow this and additional works at: https://digitalcommons.usf.edu/numeracy

Part of the Mathematics Commons, and the Science and Mathematics Education Commons

\section{Recommended Citation}

Wallace, Dorothy. "Parts of the Whole: Teachers and the Work They Do." Numeracy 1, Iss. 2 (2008): Article 8. DOI: http://dx.doi.org/10.5038/1936-4660.1.2.8 


\title{
Parts of the Whole: Teachers and the Work They Do
}

\author{
Abstract \\ This introductory column argues the need to study our system of education with the same care we would \\ give any complex system, pointing out some ways in which the educational system functions differently \\ from other managed systems, and concluding that a careful study of the forces shaping education will \\ lead to insight into what makes educational change successful. \\ Creative Commons License \\ (c) (i) (9)
}

This work is licensed under a Creative Commons Attribution-Noncommercial 4.0 License 


\section{Parts Of The Whole D. Wallace}

The problem of how best to improve the numeracy of a society is a thorny one, embracing the learning process of a single student but rising in scale to include the management and alteration of an entire system of education. With the issue of quantitative literacy always in mind, this column considers various aspects of the systemic workings of education, the forces acting on classrooms, teachers and students, and mechanisms of both stasis and change.

\section{Teachers and the work they do}

As of this writing, our appreciation of teachers and the work they do for this country seems to have reached an all-time low. The motivation for writing this column comes from a place of deep respect for public school teachers who, year after year, take all comers and attempt to do right by them.

Teaching has gotten more complicated as schools try to respond to constant evaluation and testing, evolving standards, and a politicized system. The push to include numeracy, quantitative reasoning, or quantitative literacy, as a fundamental educational goal, contributes to this complexity. Can teachers really change things by pushing themselves and their students harder? Is change impossible? We will take a careful look at the educational system in this column, treat it as a system, and study it accordingly. Teachers work, not as isolated craftsmen, but as part of a national enterprise beyond their control.

We will see some implications of such a situation. Improving the quantitative literacy of an entire population is a cultural goal. It will succeed or fail in the context of the entire educational system, not to mention the society in which it sits. The interaction between a stable, functioning system and a new demand placed upon it will necessarily alter both the system and the nature of the demand itself. We need to understand this dialectic in order to make sure that the goals of quantitative literacy are not lost in translation to the classroom, and also to be sure that other equally worthy goals are not sacrificed in the process.

One of many things that leaders in education need is a roadmap and a set of navigational tools for understanding the system they are trying to steer. Common sense tells us that setting goals and standards are not nearly enough. Every school must devise strategies for meeting those standards. Trial and error is not the best procedure for finding what works. I hope to draw on some of the most insightful 
observations in cognition, statistics, dynamical systems, and also appeals to reason, in order to offer a framework for proceeding with educational change. Everything from setting classroom priorities to determining system-wide goals can benefit from such study.

As the reader will soon see, these short essays will not carry a particularly political stance. There are no arguments for pouring funding into this or that, or removing funding from certain programs. This column explores how education works, in the hope that the intelligent application of understood principles could be used to help make a large system function more smoothly and beneficially for both students and teachers. The aim is to treat the whole system with care and critical analysis, to treat all teachers with respect, to treat the students with compassion.

Recent comparisons of the performance of U.S. students against similar students in other countries, such as the TIMMS study (Gonzales, 2004). have led many to worry about a growing lack of competitiveness in the U.S. workforce. The increasing number of technical and scientific professionals imported from other countries strengthens this perception. College faculty and administrators note widespread lack of preparation for college, resulting in a large amount of "remedial" courses being offered, especially at publicly funded two-year institutions. The business community complains that a lack of quantitative literacy among employees hampers the functioning of business. One could devote volumes to examining all the confusing claims made by the various parties to the discussion and we could try in vain to examine the validity of each argument made. So many bucks are being passed.

Education is a system, but it is also a hierarchy. When the many bucks being passed around land in the classroom, they stop there. Teachers have no one on whom they may lay the blame except the voters and parents, who traditionally refuse to accept it. The children are vote-less and thus defenseless. The teachers and students remind one of the workers described by statistician W. Edwards Deming,, (Deming, 1982), to whom this column will owe much. Deming's workers, provided with faulty materials and inappropriate tools, are none-the-less held responsible for the quality of what they produce. They, too, work within a system. They are at the bottom of the system's hierarchy and the management has decided, for convenience's sake, that the buck will stop with them. In the situation Deming describes, like that of education, the management has failed to manage.

Successful large businesses, productive manufacturing plants, and the "freemarket" economy of this country are all managed systems. Some would like to take one of these systems as a prototype for managing education. Such a strategy would be a disastrous mistake. None of these three examples are sufficiently similar to each other that management strategies are identical; and education 
differs substantially from each of them. It is absolutely necessary to study the educational system as it really is, and not as we would wish it to be. Only then will a useful strategy appear. On the other hand, many tools for analyzing systems in general are at our disposal, and we would do well to take full advantage of what we might learn from them.

As an example of the difference in systems, let us compare the situation managers face in a business versus the management of a school or school system. The managers of a business have the freedom to employ only those who suit their criteria, and to decline jobs to any unqualified person. The teacher, on the other hand, can send no student away. A business can adjust its size to optimize its efficiency, hiring more people as it grows or laying them off if it must shrink. The school must take every child in its district, no matter whether there are enough teachers or classrooms, no matter whether the budget has risen or fallen. A business produces a limited number of products and can eliminate a product line or start a new one if deemed profitable. A school produces educated people running a gamut of ability, motivation and talent as large as all humanity. Clearly, the management issues and strategies will be substantially different for these very different institutions. In fact, no business would survive under the constraints imposed on the educational system.

The biggest difference between education and other systems can be summed up in one word: democracy. The commitment to provide a decent education for an entire citizenry is something of which this country should be immensely proud. Business can reject any job applicant, manufacturing can reject faulty raw materials, the free market destroys any business that is not economically viable. The public school takes everybody and their baggage too. It should be a huge comfort to all readers to think that at least one source of the challenge to improving education is the result of a strong moral commitment to a fundamentally democratic principle.

It would not be surprising if such an important factor accounted for some of the differences among countries in student performance on standardized tests. The U.S. might look a good deal better if its competition had to average in the performance of those children who missed the educational experience entirely. The easiest way to increase a mean score is to define the bottom few percentiles of the potential test takers as simply not being in the test population. In any case, improvement in our educational system must be measured against our needs, and not against other nations.

If anything, our educational system is more like a biological system than anything else, children representing the ultimate renewable national resource. It might be hard to think of them that way, as they usually appear to be using up resources rather than providing any. But any of us who hope to collect retirement benefits of any sort had better help the kids grow up to be astute businesspeople, 
brilliant scientists, moral politicians and yes, excellent teachers. At some point in the not-too-distant future we will all be living off their day-to-day success.

\section{References}

Deming, W. Edwards. 1982. Out of the Crisis, Cambridge MA: MIT press.

Gonzales, Patrick, Juan Carlos Guzman, Lisette Partelow, Erin Pahlke, Leslie Jocelyn, David Kastberg, and Trevor Williams. 2004. Highlights From the Trends in International Mathematics and Science Study: TIMSS 2003. http://nces.ed.gov/pubsearch/pubsinfo.asp?pubid=2005005 (accessed June 24, 2008) 